\title{
Pengaruh Ukuran Perusahaan dan Profitabilitas Terhadap Struktur Modal
}

\section{Pada Perusahaan Makanan dan Minuman di Indonesia}

\section{Dyan Nur Aulia}

Universitas Muhammadiyah Prof. DR. HAMKA

dyan.aulia96@gmail.com

\section{ABSTRACT}

The research method used in this study is a quantitative method, the independent variables used in this study consist of company size, and profitability while the dependent variable is the capital structure. The population in this study are food and beverage sector manufacturing companies listed on the Indonesia Stock Exchange (IDX) listed on the Indonesia Stock Exchange 2013-2017 period. Sample selection through purposive sampling method. There are 9 (nine) companies that have criteria as research samples, so that the research data totaled 45 data. Data collection techniques used are document review, the data analyzed are annual financial reports (annual report), previous research journals and other literature relating to research problems. Data processing and analysis techniques include financial management analysis, multiple linear regression analysis, classic assumption test, hypothesis test, coefficient of determination test and coefficient of determination test. The results showed that the company size partially had no effect and no significant effect on capital structure, and profitability was partially positive and significant effect on capital structure. While simultaneously the size of the company, and profitability affect the capital structure.

\section{Keywords: Company Size; Profitability; Capital Structure}




\begin{abstract}
ABSTRAK
Metode penelitian yang digunakan dalam penelitian ini adalah metode kuantitatif, variabel independen yang digunakan dalam penelitian ini terdiri dari ukuran perusahaan, dan profitabilitas sedangkan variabel dependen adalah struktur modal. Populasi dalam penelitian ini adalah perusahaan manufaktur sektor makanan dan minuman yang terdaftar di Bursa Efek Indonesia (BEI) yang terdaftar di Bursa Efek Indonesia periode 2013-2017. Pemilihan sampel melalui metode purposive sampling. Terdapat 9 (sembilan) perusahaan yang memiliki kriteria sebagai sampel penelitian, sehingga data penelitian berjumlah 45 data. Teknik pengumpulan data yang dilakukan adalah telaah dokumen, data yang ditelaah adalah laporan keuangan tahunan (annual report), jurnal penelitian terdahulu dan literatur lain yang berkaitan dengan masalah penelitian. Teknik pengolahan dan analisis data meliputi analisis manajemen keuangan, analisis regresi linier berganda, uji asumsi klasik, uji hipotesis, uji koefisien determinasi dan uji koefisien determinasi. Hasil penelitian menunjukkan bahwa secara parsial ukuran perusahaan tidak berpengaruh dan tidak signifikan terhadap struktur modal, dan profitabilitas secara parsial berpengaruh positif dan signifikan terhadap struktur modal. Sedangkan secara simultan ukuran perusahaan, dan profitabilitas berpengaruh terhadap struktur modal.
\end{abstract}

Kata kunci: Ukuran Perusahaan; Profitabilitas; Struktur Modal 


\section{PENDAHULUAN}

Di era globalisasi yang berkembang pesat sekarang membuat persaingan perusahaan semakin tajam. Hal ini membuat perusahaan untuk melakukan kegiatan secara efektif dan efisien sehingga mereka tetap dapat bersaing dengan perusahaan lain. Fungsi keuangan dalam perusahaan memiliki peran yang sangat penting, karena manajemen keuangan masuk dan keluar perusahaan dikelola oleh departemen keuangan. Sumber dana perusahaan dapat berasal dari sumber internal atau eksternal. Dana dari sumber internal dapat dalam bentuk modal sendiri, modal saham, laba ditahan dan dana cadangan. Sedangkan dana yang berasal dari sumber eksternal bisa dalam bentuk dana pihak ketiga atau utang (Ruzikna dan Wulandari, 2018; Premawati dan Darma, 2017).

Perusahaan yang bergerak di subsektor makanan dan minuman, Industri Makanan dan Minuman menjadi subsektor prioritas pada 2018. Subsektor tersebut diharapkan menjadi pendorong untuk tercapainya target pertumbuhan industri non-migas tahun 2018, yakni 5,67 persen. Menurut Mentri Perindustrian sektor ini juga meningkatkan realisasi investasi, selain itu sektor industri makanan dan minuman Indonesia berkontribusi $34 \%$ terhadap industri Indonesia (Tempo.co, 26 Desember 2018). Kinerja positif para pemain telah membuka peluang baru untuk bersaing di pasar internasional. Menteri Perindustrian Airlangga Hartarto mengatakan, sektor ini dapat menjadi contoh penerapan teknologi Industri 4.0 di Indonesia. Selain itu, nilai ekspor food and beverage nasional pada 2017 berdasarkan data Kementerian Perindustrian (Kemenperin) mencapai US\$11,5 miliar. Jumlah ini meningkat dibandingkan 2016 yang mencapai US\$10,43 miliar. Di sisi lain, pertumbuhan sektor ini (9,23\%) melampaui jumlah PDB nasional (5,07\%) (Marketeers.com, 23 Maret 2018).

Modal adalah instrumen yang sangat penting dalam mendukung keberlanjutan perusahaan, terutama perusahaan manufaktur yang bergerak di sektor makanan dan minuman. Seiring dengan meningkatnya permintaan konsumen akan barang untuk kebutuhan sehari-hari, kebutuhan perusahaan juga akan menambah modal perusahaan itu sendiri. Faktor-faktor yang mempengaruhi struktur modal perusahaan adalah penting sebagai dasar pertimbangan dalam menentukan komposisi struktur modal suatu perusahaan. Banyak faktor yang mempengaruhi keputusan struktur modal. Menurut Brigham dan Houston (2013) menyatakan bahwa ada beberapa faktor yang mempengaruhi pengambilan keputusan modal, termasuk stabilitas penjualan, struktur aset, leverage operasi, tingkat pertumbuhan, kondisi pasar, fleksibilitas keuangan, ukuran perusahaan dan profitabilitas. Namun dalam penelitian ini semua faktor yang 
mempengaruhi keputusan struktur modal perusahaan akan dibahas, hanya beberapa faktor yang akan dibahas dalam penelitian ini termasuk ukuran perusahaan dan profitabilitas.

Struktur modal adalah kombinasi dari modal dan modal yang dimiliki oleh perusahaan. subjek struktur modal adalah topik yang dapat diperdebatkan di antara akademisi di dunia keuangan perusahaan dan diberikan secara luas di negara-negara barat. (InunJariya, 2015; Indradinata et all., 2019). Sementara itu, menurut Anandasayanan dan Subramania (2018) struktur modal gabungan dari beberapa saham ekuitas jangka panjang dan sumber pendanaan termasuk surplus dan cadangan perusahaan. Struktur modal suatu perusahaan adalah kombinasi dari keuangannya dan modalnya tidak pasti tetapi merupakan sumber daya penting bagi semua perusahaan, lembaga keuangan yang dapat menerapkan kontrol atas perusahaan. Ekuitas dan Utang adalah mayoritas perusahaan, dengan pemilik Utang dan Utang atas nama dua jenis investor di perusahaan. Masing-masing terkait dengan berbagai tingkat risiko, manfaat, dan kontrol.

Adapun faktor - faktor yang mempengaruhi struktur modal perusahaan merupakan hal penting sebagai dasar pertimbangan dalam menentukan komposisi strruktur modal suatu perusahaan. Banyak faktor yang mempengaruhi keputusan struktur modal. Menurut Brigham dan Houston (2013) menyatakan ada beberapa faktor yang berpengaruh dalam pengambilan keputusan struktur modal diantaranya yaitu stabilitas penjualan, struktur aktiva, leverage operasi, tingkat pertumbuhan, kodisi pasar, fleksibilitas keuangan, ukuran perusahaan dan profitabilitas.

Di antara para peneliti, ada dua teori utama yang dapat diterapkan di perusahaan, yaitu Pecking Order Theory dan Trade Off Theory. Yang pertama didirikan oleh Myers \& Majluf (1984), dan didasarkan pada asimetri informasi antara investor dan manajer perusahaan. Perusahaan lebih memilih pembiayaan internal daripada pembiayaan eksternal, tetapi dalam hal persyaratan pembiayaan eksternal, utang lebih disukai. Teori ini tidak mengambil struktur modal yang optimal sebagai target, tetapi menggunakan preferensi perusahaan untuk menggunakan sumber internal daripada sumber eksternal sebagai titik awal. Yang kedua adalah teori Trade off yang tumbuh dari perdebatan tentang teorema Modigliani-Mill (Modigliani \& Miller, 1963). Pajak penghasilan perusahaan ditambahkan ke ketidaksesuaian awal yang pada gilirannya menciptakan manfaat untuk utang. Teori trade-off mengasumsikan bahwa perusahaan memperdagangkan manfaat dan biaya pembiayaan utang dan ekuitas dan menemukan struktur modal yang optimal dengan mempertimbangkan manfaat pajak, biaya kebangkrutan, dan biaya agensi. Teori-teori ini membantu untuk memahami sifat struktur 
modal perusahaan dan juga mengidentifikasi faktor internal dan eksternal yang potensial (Harjito, 2011).

Ukuran perusahaan dapat didefinisikan sebagai logaritma total aset dan logaritma penjualan. Sebagian besar penelitian telah menemukan hubungan positif antara ukuran perusahaan dan leverage perusahaan (Deesomsak et all., 2004; Rajan dan Zingales, 1995; Handayani et all., 2018). Ini konsisten dengan teori perdagangan (TOT) di mana perusahaan besar memiliki kecenderungan lebih tinggi untuk menggunakan lebih banyak utang. Namun, Chen (2004) dan Ooi (1999) berpendapat bahwa ada hubungan terbalik antara ukuran perusahaan dan leverage perusahaan karena, perusahaan kecil memiliki akses terbatas ke modal ekuitas dan lebih suka memberikan pinjaman kepada bank. Ukuran perusahaan besar memungkinkan perusahaan mendapatkan pengembalian aset dan penjualan yang tinggi, dan ini sangat memengaruhi kinerja keuangan perusahaan yang baik melalui kemampuan perusahaan untuk mendapatkan nilai produksi yang lebih tinggi dan kemampuan perusahaan untuk melunasi utangnya. (Ramli, Latan, \& Solovida, 2018).

Profitabilitas merupakan kemampuan suatu perusahaan untuk menghasilkan laba selama periode tertentu. Profitabilitas diukur dengan kesuksesan perusahaan dan kemampuan menggunakan aktivanya secara produktif, dengan demikian profitabilitas suatu perusahaan dapat diketahui dengan membandingkan antara laba yang diperoleh dalam suatu periode dengan jumlah aktiva atau jumlah modal perusahaan tersebut (Munawir, 2014 Riadevi dan Darma, 2016).

Menurut Brigham \& Houston (2011: 188) bahwa variabel profitabilitas dapat mempengaruhi struktur modal. Profitabilitas adalah kemampuan perusahaan untuk memperoleh laba. Semakin besar keuntungan yang diperoleh perusahaan, perusahaan menggunakan manfaat ini untuk membiayai operasi perusahaan sehingga dapat meminimalkan kemungkinan perusahaan berutang, profitabilitas yang tinggi juga dapat mencerminkan kinerja perusahaan yang baik sehingga investor dapat menarik modal ke perusahaan dan akan mempengaruhi harga saham yang nantinya akan mencerminkan nilai perusahaan yang akan tinggi (Rachmawati, et al: 2015). Profitabilitas suatu perusahaan tergantung pada situasi ekonomi pasar di mana ia beroperasi dan karakteristik perusahaan, seperti ukuran dan spesifikasi aset, reputasi, dan usia perusahaan (Jansakul \& Petchsakulwong, 2017).

\section{Struktur Modal}

Struktur modal berhubungan dengan sumber pendanaan untuk perusahaan. Keputusan dalam pemilihan sumber pendanaan perusahaan merupakan keputusan dalam bidang keuangan 
yang sangat penting bagi perusahaan dalam menciptakan nilai bagi perusahaan (Ristiani, 2015). Selain itu, struktur modal juga merupakan perbandingan antara besaran modal sendiri dengan modal yang berasal dari pihak ekstern perusahaan atau hutang. Struktur modal menunjukkan rasio yang menggambarkaan besaran hutang yang dimiliki oleh sebuah perusahaan. Rasio struktur modal yang lebih dari 1 menunjukkan hutang atau kewajiban perusahaan tersebut lebih besar dari pada total aktiva atau modal yang dimiliki perusahaan tersebut (Cahyo $d k k$., 2013).

\section{Ukuran Perusahaan}

Menurut Mulyo (2013) semakin besar ukuran perusahaan yang diindikatori oleh total aset, maka perusahaan akan menggunakan hutang dalam jumlah yang besar pila. Semakin besar ukuran perusahaan menunjukkan bahwa perusahaan tersebut memiliki jumlah aktiva yang semakin tinggi pula. Perusahaan yang ukurannya relatif besar pun akan cenderung menggunakan dana eksternal yang semakin besar

\section{Profitabilitas}

Profitabilitas adalah tingkat keuntungan bersih yang mampu diraih oleh perusahaan pada saat menjalankan operasinya. Profitabilitas mencerminkan kemampuan perusahaan dalam menghasilkan laba ditahan, sesuai dengan pecking order theory yang mempunyai prefensi pendanaan pertama dengan dana internal berupa laba ditahan sehingga komponen modal sendiri semakin meningkat. Dengan meningkatkan modal sendiri, maka rasio hutang menjadi menurun dengan asumsi hutang relatif tetap (Mulyo dkk, 2013).

\section{Kerangka Pemikiran}

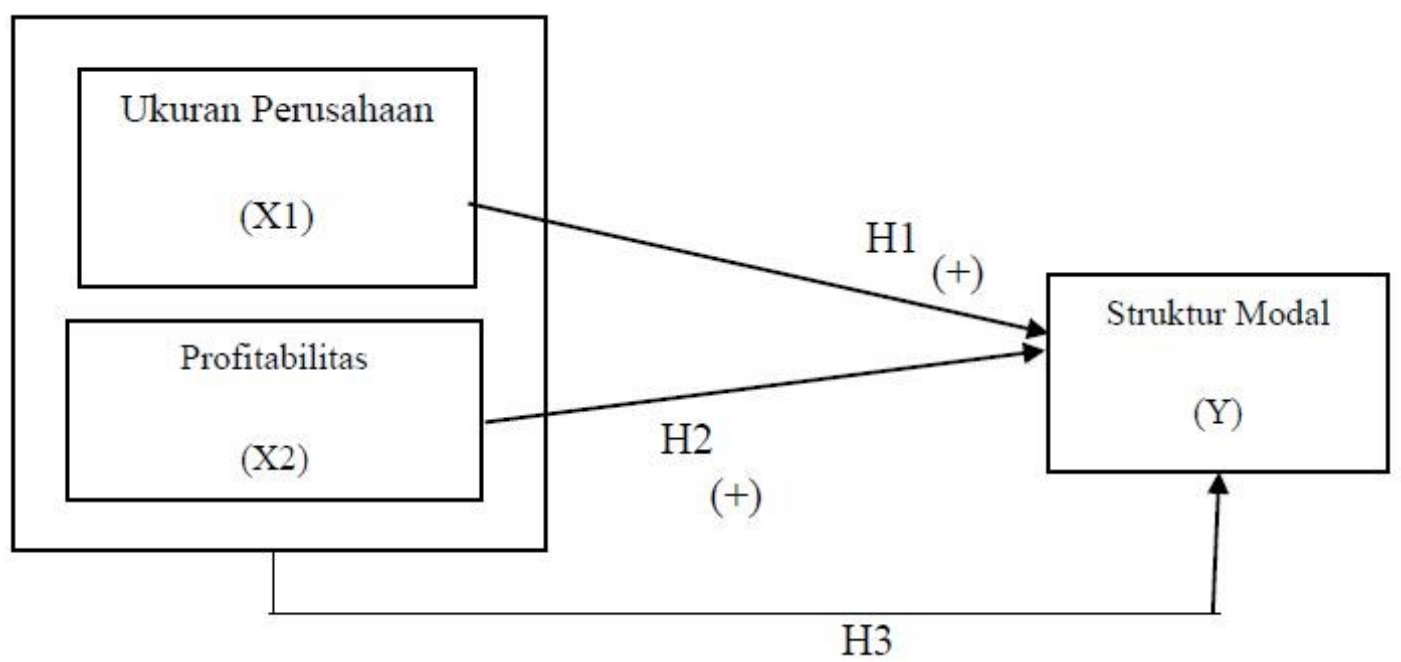

Gambar 1

Kerangka Pemikiran Teoritis 


\section{METODE PENELITIAN}

\section{Desain Penelitian}

Penelitian ini merupakan penelitian kuantitatif. Dalam penelitian ini menggunakan data sekunder dimana populasi dan sampel dalam penelitian ini adalah laporan keuangan tahunan perusahaan yang terdaftar di Bursa Efek Indonesia 2013-2017. Data dalam penelitian ini adalah data deret waktu dengan teknik pengumpulan data menggunakan penelitian kepustakaan dan dokumentasi.

\section{Teknik Analisis Data}

Metode yang digunakan dalam penelitian ini adalah uji asumsi klasik, uji multikolinieritas, uji autokorelasi, uji heteroskedastisitas, analisis regresi linier berganda, Pengujian hipotesis, uji parsial (uji t statistik), uji simultan (uji F statistik), dan analisis koefisien determinan $(\mathrm{R} \neg 2)$ dengan menggunakan SPSS 24.0.

\section{HASIL \& PEMBAHASAN}

ANALISIS DATA

Uji Asumsi Klasik

\section{Uji Normalitas}

\section{Tabel 1 : Uji Normalitas \\ Kolmogorov-Smirnov}

One-Sample Kolmogorov-Smirnov Test

\begin{tabular}{|c|c|c|}
\hline & & $\begin{array}{l}\text { Unstandardiz } \\
\text { ed Residual }\end{array}$ \\
\hline N & & 45 \\
\hline \multirow[t]{2}{*}{ Normal Parameters ${ }^{a, b}$} & Mean & .0000000 \\
\hline & Std. Deviation & .34177238 \\
\hline \multirow[t]{3}{*}{ Most Extreme Differences } & Absolute & .106 \\
\hline & Positive & .064 \\
\hline & Negative & -.106 \\
\hline \multicolumn{2}{|l|}{ Test Statistic } & .106 \\
\hline \multicolumn{2}{|l|}{ Asymp. Sig. (2-tailed) } & $.200^{\mathrm{c}, \mathrm{d}}$ \\
\hline \multicolumn{3}{|c|}{ a. Test distribution is Normal. } \\
\hline \multicolumn{3}{|l|}{ b. Calculated from data. } \\
\hline \multicolumn{3}{|c|}{ c. Lilliefors Significance Correction. } \\
\hline \multicolumn{3}{|c|}{ d. This is a lower bound of the true significance. } \\
\hline
\end{tabular}

Sumber: Output SPSS 24.0, 2019

Pada tabel 1 di atas menunjukkan bahwa hasil keluaran dengan uji KolomogorovSmirnov memiliki model regresi yang baik. Karena nilai signifikansi lebih besar, yaitu 
0,200>0,05, dapat ditafsirkan bahwa residu terdistribusi secara normal. Hasil Uji

Kolmogorov-Smirnov juga didukung oleh hasil analisis grafik plot P-P normal.

\section{Normal P-P Plot Graph}

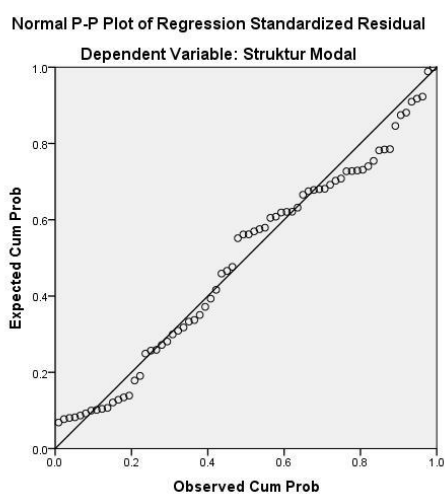

Sumber : Output SPSS 24.0, 2019

Berdasarkan Gambar 1 di atas hasil dari grafik P-Plot normal di atas, polanya menunjukkan penyebaran titik-titik di sekitar garis diagonal dan mengikuti arah garis diagonal sehingga dapat disimpulkan bahwa model regresi memenuhi asumsi normalisasi. Kesimpulan keseluruhan yang dapat diambil adalah bahwa nilai observasi dari data telah terdistribusi normal dan dapat dilanjutkan dengan tes asumsi klasik lainnya.

\section{Uji Multikolonieritas}

Tabel 2 : Uji Multikolonieritas

\begin{tabular}{|c|c|c|c|c|c|c|c|c|}
\hline \multicolumn{9}{|c|}{ Coefficients $^{a}$} \\
\hline & & \multicolumn{2}{|c|}{ Unstandardized Coefficients } & \multirow{2}{*}{$\begin{array}{c}\text { Standardized } \\
\text { Coefficients } \\
\text { Beta }\end{array}$} & \multirow[b]{2}{*}{$\mathrm{t}$} & \multirow[b]{2}{*}{ Sig. } & \multicolumn{2}{|c|}{ Collinearity Statistics } \\
\hline \multicolumn{2}{|l|}{ Model } & B & Std. Error & & & & Tolerance & VIF \\
\hline \multirow[t]{3}{*}{1} & (Constant) & 1.275 & 1.368 & & .932 & .356 & & \\
\hline & Ukuran Perusahaan & -.019 & .047 & -.050 & -.395 & .695 & .979 & 1.022 \\
\hline & Profitabilitas & .829 & .203 & .514 & 4.092 & .000 & .979 & 1.022 \\
\hline
\end{tabular}

a. Dependent Variable: Struktur Modal

Sumber : Output SPSS 24.0, 2019

Berdasarkan tabel 2 di atas, itu menunjukkan bahwa hasil uji multikolinieritas menunjukkan bahwa ukuran perusahaan independen (X1) dan Profitabilitas (X2) memiliki nilai toleransi $>0,10$ dengan nilai VIF $<10$. Hasil perhitungan Ukuran Perusahaan VIF adalah 1,022 
$<10$ dan Profitabilitas adalah $1,022<10$, sehingga dapat diartikan tidak terjadinya multikolinieritas antara variabel independen dalam penelitian ini.

\section{Uji Autokorelasi}

Pengujian untuk ada tidaknya autokorelasi dilakukan dengan menggunakan metode Durbin-Watson. Cara mendeteksi autokorelasi dalam model analisis regresi menggunakan DW menurut Singgih Santoso (2014), dapat dijelaskan:

1. Jika nilai D-W terletak di bawah -2, ada autokorelasi positif

2. Jika nilai $\mathrm{D}-\mathrm{W}$ terletak antara -2 hingga +2 , tidak ada autokorelasi

3. Jika nilai $\mathrm{D}-\mathrm{W}$ terletak di atas +2 , ada autokorelasi positif

\section{Tabel 3 : Uji Autokorelasi}

\begin{tabular}{|c|c|c|c|c|c|}
\hline \multicolumn{6}{|c|}{ Model Summary ${ }^{b}$} \\
\hline Model & $R$ & R Square & $\begin{array}{l}\text { Adjusted R } \\
\text { Square }\end{array}$ & $\begin{array}{l}\text { Std. Error of } \\
\text { the Estimate }\end{array}$ & $\begin{array}{l}\text { Durbin- } \\
\text { Watson }\end{array}$ \\
\hline 1 & $.667^{\mathrm{a}}$ & .445 & .419 & .34982 & 1.334 \\
\hline
\end{tabular}

Sumber : Output SPSS 24.0, 2019

Dari data di atas kita dapat melihat bahwa nilai Durbin Watson (DW Statistik) dari hasil analisis regresi adalah 1,334, nilai DW terletak antara -2 hingga +2 sehingga dapat dipastikan bahwa model regresi linier berganda tidak memiliki Autokorelasi.

\section{Uji Heterokedastisitas}

Persamaan regresi yang baik jika tidak ada heteroskedastisitas (Ghozali, 2016: 134). Dalam penelitian ini metode bagan (diagram sebaran) akan digunakan dengan premis bahwa:

1. Jika ada pola tertentu, seperti titik yang membentuk pola tertentu yang teratur (bergelombang, melebar dan kemudian menyempit), maka itu menunjukkan bahwa heteroskedastisitas telah terjadi.

2. Jika ada pola yang jelas, dan titik-titik menyebar di atas dan di bawah angka 0 pada sumbu Y, tidak ada heteroskedastisitas. 
Tabel 4 : Heterokedastisitas

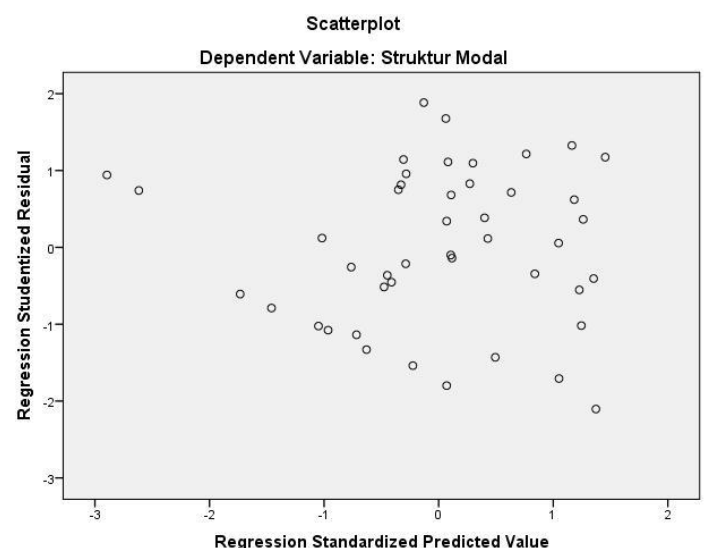

Sumber : Output SPSS 24.0, 2019

Berdasarkan grafik sebar gambar di atas menunjukkan bahwa tidak ada pola yang jelas dan titik-titik menyebar secara acak baik di atas maupun di bawah angka 0 (nol) pada sumbu Y, maka dapat diartikan bahwa tidak ada heteroskedastisitas dalam penelitian ini.

\section{Analisis Regresi Linier Berganda}

Table 5 : Regresi Linier Berganda

\section{Coefficients $^{a}$}

\begin{tabular}{|c|c|c|c|c|c|c|}
\hline \multirow[b]{2}{*}{ Model } & & \multicolumn{2}{|c|}{ Unstandardized Coefficients } & \multirow{2}{*}{$\begin{array}{c}\text { Standardized } \\
\text { Coefficients } \\
\text { Beta } \\
\end{array}$} & \multirow[b]{2}{*}{$\mathrm{t}$} & \multirow[b]{2}{*}{ Sig. } \\
\hline & & $\mathrm{B}$ & Std. Error & & & \\
\hline \multirow[t]{3}{*}{1} & (Constant) & 1.275 & 1.368 & & .932 & .356 \\
\hline & Ukuran Perusahaan & -.019 & .047 & -.050 & -.395 & .695 \\
\hline & Profitabilitas & .829 & .203 & .514 & 4.092 & .000 \\
\hline
\end{tabular}

a. Dependent Variable: Struktur Modal

Sumber : Output SPSS 24.0, 2019

Berdasarkan hasil pengujian analisis regresi linier berganda pada tabel 5 di atas, persamaan regresi dapat diperoleh untuk mengetahui faktor-faktor dalam memprediksi / memprediksi nilai-nilai perusahaan sebagai berikut:

$Y=1.275-0.019 \mathrm{X} 1+0.829 \mathrm{X} 2$ 
Dari persamaan regresi linier berganda dapat dijelaskan sebagai berikut:

a : Angka konstan 1.275 berarti Ukuran Perusahaan (X1), Profitabilitas (X2) sama dengan 0 (nol), maka Struktur Modal potensial (Y) di perusahaan sub-sektor makanan dan minuman yang terdaftar di Bursa Efek pada 2013-2017 adalah 1.275.

b : Koefisien regresi dari variabel Ukuran Perusahaan (X1) bernilai (negatif) sebesar 0,019, yang berarti bahwa koefisien regresi Ukuran Perusahaan (XI) pada Struktur Modal (Y) di sub-sektor makanan dan minuman yang terdaftar di Bursa Efek di 20132017 negatif, artinya Menolak Ukuran Perusahaan meningkat sebesar 1\%, Struktur Modal pada 2013-2017 meningkat sebesar 0,019\%, dan berubah, b2: Koefisien regresi variabel Profitabilitas (X2) bernilai (positif) sebesar 0,829, artinya jika profitabilitas perusahaan di sub-sektor makanan dan minuman meningkat 1\%, Struktur Modal pada 2013 -2017 akan meningkat 0,829\%, dan berubah.

\section{Pengujian Hipotesis}

\section{Uji Parsial (Uji T Statistik)}

Berdasarkan tabel 6 di bawah ini, hipotesis dilakukan dengan membandingkan t-hitung dan t-tabel pada tingkat kepercayaan $5 \%=(0,05)$, jumlah data $(\mathrm{n})$ valid sebanyak 45 , jumlah variabel $(\mathrm{k})$ adalah $2 \mathrm{dan} \mathrm{df}=\mathrm{nk}-1$. Sehingga dapat dilihat nilai $\mathrm{df}=42$, diperoleh dengan $\mathrm{t}$ tabel sebesar 2,01808. Berikut ini adalah hasil perhitungan Uji Parsial (Uji Statistik t) menggunakan perangkat lunak SPSS 24.0:

Tabel 6 : Uji T Statistik

\begin{tabular}{|c|c|c|c|c|c|c|c|c|}
\hline \multicolumn{9}{|c|}{ Coefficients $^{a}$} \\
\hline & & \multicolumn{2}{|c|}{ Unstandardized Coefficients } & \multirow{2}{*}{$\begin{array}{c}\text { Standardized } \\
\text { Coefficients } \\
\text { Beta }\end{array}$} & \multirow[b]{2}{*}{$\mathrm{t}$} & \multirow[b]{2}{*}{ Sig. } & \multicolumn{2}{|c|}{ Collinearity Statistics } \\
\hline \multicolumn{2}{|l|}{ Model } & B & Std. Error & & & & Tolerance & VIF \\
\hline \multirow[t]{3}{*}{1} & (Constant) & 1.275 & 1.368 & & .932 & .356 & & \\
\hline & Ukuran Perusahaan & -.019 & .047 & -.050 & -.395 & .695 & .979 & 1.022 \\
\hline & Profitabilitas & .829 & .203 & .514 & 4.092 & .000 & .979 & 1.022 \\
\hline
\end{tabular}

a. Dependent Variable: Struktur Modal

Sumber : Output SPSS 24.0, 2019 


\section{Uji Simultan (Uji F Statistik)}

Uji F digunakan untuk menguji signifikansi pengaruh variabel independen secara simultan terhadap variabel dependen. Langkah-langkah yang diambil dalam menguji hipotesis pertama adalah sebagai berikut:

H_0 : Tidak ada pengaruh yang signifikan, Ukuran Perusahaan (X1), dan Profitabilitas (X2) secara simultan pada Struktur Modal (Y).

H_1 : Ada pengaruh yang signifikan, Ukuran Perusahaan (X1), dan Profitabilitas (X2) secara simultan pada Struktur Modal (Y).

Jika hitung statistik (angka F output)> Tabel Statistik (tabel F), maka H_0 ditolak.

Dan jika statistik hitung (angka F output) <Tabel Statistik (tabel F), maka H_0 diterima.

\section{Tabel 7 : Uji F Statistik}

\begin{tabular}{|c|c|c|c|c|c|c|}
\hline \multicolumn{7}{|c|}{ ANOVA $^{a}$} \\
\hline Model & & $\begin{array}{l}\text { Sum of } \\
\text { Squares }\end{array}$ & df & Mean Square & $\mathrm{F}$ & Sig. \\
\hline \multirow[t]{3}{*}{1} & Regression & 4.123 & 2 & 2.062 & 16.848 & $.000^{\mathrm{b}}$ \\
\hline & Residual & 5.140 & 42 & .122 & & \\
\hline & Total & 9.263 & 44 & & & \\
\hline
\end{tabular}

Sumber : Output SPSS 24.0, 2019

Berdasarkan tabel di atas $\mathrm{F}_{-}$count adalah 16,848> T tabel adalah 4,07 dengan signifikansi 0,000 yang nilainya jauh lebih kecil dari 0,05, maka $\mathrm{H}_{-} 1$ diterima dan menolak H_0. Ini menunjukkan bahwa Ukuran Perusahaan (X1), dan Profitabilitas (X2) secara simultan mempengaruhi Struktur Modal perusahaan sub-sektor makanan dan minuman yang terdaftar di Bursa Efek untuk periode 2013-2017.

\section{Analisis Koefisien Determinan (R2)}

Nilai kecil (R2) berarti kemampuan variabel independen untuk menjelaskan variasi dalam variabel dependen sangat terbatas. Nilai yang mendekati satu berarti bahwa variabel menyediakan hampir semua informasi yang diperlukan untuk memprediksi variasi dalam variabel dependen. 
Tabel 8 : Analisis Koefisien Determinan ( R2 )

\begin{tabular}{|c|c|c|c|c|c|c|c|c|c|c|}
\hline \multirow[b]{3}{*}{ Model } & \multicolumn{10}{|c|}{ Model Summary ${ }^{b}$} \\
\hline & & & & & & & e Statisti & & & \\
\hline & $\mathrm{R}$ & R Square & $\begin{array}{l}\text { Adjusted R } \\
\text { Square }\end{array}$ & $\begin{array}{l}\text { Std. Error of } \\
\text { the Estimate }\end{array}$ & $\begin{array}{c}\text { R Square } \\
\text { Change }\end{array}$ & F Change & df1 & $\mathrm{df} 2$ & $\begin{array}{l}\text { Sig. } F \\
\text { Change }\end{array}$ & $\begin{array}{l}\text { Durbin- } \\
\text { Watson }\end{array}$ \\
\hline 1 & $.667^{\mathrm{a}}$ & .445 & .419 & .34982 & .445 & 16.848 & 2 & 42 & .000 & 1.334 \\
\hline
\end{tabular}

Sumber : Output SPSS 24.0, 2019

Dari tabel 8 di atas, dapat dilihat bahwa koefisien determinasi Adjusted R Square adalah 0,419. Kemudian dapat diartikan bahwa 41,9\% dari Struktur Modal dapat dijelaskan oleh semua variabel independen yang terdiri dari Ukuran Perusahaan (X1), dan Profitabilitas (X2), sedangkan sisanya $58,1 \%$ dipengaruhi oleh variabel lain yang tidak termasuk dalam model penelitian.

\section{Hasil Penelitian}

Dalam penelitian ini ukuran perusahaan secara parsial tidak berpengaruh dan tidak signifikan terhadap struktur modal, ini dapat menjadi bukti bahwa ukuran perusahaan tidak dapat menjadi penentu dalam menentukan penggunaan struktur modal. Setiap penggunaan dana, baik modal sendiri maupun modal asing, berbeda dalam biaya modal. Perusahaan dengan skala besar dan kecil akan menggunakan sumber pendanaan yang lebih aman, yaitu pendanaan internal, dari pada menggunakan pendanaan eksternal. Profitabilitas berpengaruh positif terhadap struktur modal yang berarti bahwa semakin kecil profitabilitas yang dihasilkan oleh suatu perusahaan, struktur modal yang dihasilkan oleh suatu perusahaan akan semakin tinggi, karena profitabilitas yang rendah mencerminkan penyediaan dana internal yang tidak terlalu besar seperti teori Pecking order. jika dan secara internal mampu memenuhi sebagian besar kebutuhan pendanaan, perusahaan dapat mengurangi hutang, yang berarti bahwa dana internal adalah pilihan utama dalam memenuhi persyaratan pembiayaan. Semakin tinggi laba yang diperoleh, semakin kecil kemungkinan perusahaan untuk menggunakan utang.

\section{PENUTUP}

\section{Kesimpulan}

Kesimpulan dari penelitian ini adalah sebagai berikut: Berdasarkan penelitian pada variabel ukuran perusahaan tidak diperlukan dan tidak signifikan terhadap struktur modal perusahaan subsektor makanan dan minuman prioritas pada tahun 2013-2017. Ini menunjukkan bahwa semakin besar ukuran suatu perusahaan tidak perlu menjadi nilai Struktur 
Modal di perusahaan. Berdasarkan hasil penelitian, variabel positif dan signifikan pada struktur modal perusahaan makanan dan minuman prioritas pada tahun 2013-2017. Ini menunjukkan bahwa semakin tinggi tingkat laba yang dibuat oleh perusahaan dapat meningkatkan nilai struktur modal. Berdasarkan hasil penelitian bahwa secara simultan variabel ukuran perusahaan dan profitabilitas sangat menentukan terhadap struktur modal. Ini menunjukkan pergerakan kedua variabel tersebut dapat mempengaruhi struktur modal karena ukuran perusahaan tidak mempengaruhi struktur modal.

\section{Saran}

Berdasarkan hasil penelitian yang telah dikemukakan maka dapat dikemukakan beberapa saran. Bagi Investor, Untuk para investor yang akan menanamkan modalnya khususnya pada perusahaan sub sektor makanan dan minuman, disarankan untuk menilai struktur modal perusahaan dari berbagai faktor, salah satunya dengan mempertimbangkan variabel Profitabilitas. Karena dalam penelitian ini Profitabilitas merupakan variabel yang paling berpengaruh terhadap struktur modal. Bagi Perusahaan, Hubungan yang tidak signifikan antara Ukuran Perusahaan terhadap Strutkur Modal dan hubungan yang signifikan antara Profitabilitas terhadap Struktur Modal dapat menjadi suatu bahan pertimbangan bagi suatu perusahaan khususnya perusahaan sub sektor makanan dan minuman dalam mencapai dan mengembangkan bisnisnya. Bagi Peneliti, Dari hasil penelitian ini, bagi peneliti selanjutnya disarankan menggunakan populasi dan sampel yang lebih luas dan menambah periode pengamatan sehingga dapat memberikan hasil analisis yang lebih baik. Serta dapat mengembangkan penelitian selanjutnya mengenai variabel keuangan lainnya yang memiliki pengaruh lebih besar terhadap struktur modal. 


\section{DAFTAR PUSTAKA}

Anandasayanan, S., \& Subramaniam, A.V. (2018). Capital Structure and Stock Prices: Empirical Evidence from Listed Beverage, Food and Tobacco Companies in Sri Lanka, International Journal of Social and Administrative Sciences, 3 (2): 83-90.

Assegaf, A. (2014) Pengaruh Profitabilitas, Ukuran Perusahaan, Peluang Pertumbuhan Perusahaan, Struktur Aktiva, Risiko Bisnis, dan Non Debt Tax Shield Terhadap Struktur modal Perusahaan Food and Beverage yang terdaftar di Bursa Efek Indonesia Periode 2010-2013, Jurnal Ilmiah Mahasiswa FEB Universitas Brawijaya, 3 (1): 1-14. https://jimfeb.ub.ac.id/index.php/jimfeb/article/view/1608.

Ban, M., \& Chen, C.C. (2019). Ambiguity and Capital Structure Adjustments, International Review of Economics and Finance, https://doi.org/10.1016/j.iref.2019.05.009.

Congming, M., Anxing, W., \& Jinqiang, Y. (2016). Optimal Capital Structure with Moral Hazard, International Review of Economics and Finance. http://dx.doi.org/10.1016/j.iref.2016.12.006.

Darma, G.S. (2019). Kacamata Media, Kesuksesan Bersyarat. Indonesia: Pustaka Larasan Press.

Darma, G.S. (2018). Seuntai Pesan, Menjawab Zaman. Indonesia: Pustaka Larasan Press.

Dana, M., \& Kartika, I.K.S. (2015). Pengaruh Profitabilitas, Likuiditas, Ukuran Perusahaan, dan Tingkat Pertumbuhan Terhadap Struktur Modal Perusahaan Food And Beverages yang terdaftar di Bursa Efek Indonesia, E-Jurnal Manajemen, 4 (3): 606-625.

Giovanna, N., and Darma, G.S. (2019). Scanlated vs. Physical Japanese Comic Manga, International Journal of Innovative Science and Research Technology, 4 (1): 630-636.

Handayani, K.A.T., Maradona, A.F., and Darma, G.S. (2018). Firm Size, Business Risk, Asset Structure, Profitability, and Capital Structure, Jurnal Manajemen \& Bisnis, 15 (2): 48 57.

Indradinata, A., Suardana, I.B.R., Darma, G.S., and Maradona, A.F. (2019). Faktor Penentu Naik-Turunnya Harga Saham di Bursa Efek Indonesia, Jurnal Manajemen \& Bisnis, 16 (2): $14-35$.

Jose-San, A., L., \& Pando, V. (2018). Profitability Ratio Maximization in an Inventory Model with stock-dependent demand rate and non-linear holding cost, Applied Mathematical Modelling. 
Jezovita, A., Tusek, B., \& Zager, K. (2016). Analysis Related to Number of Small and Medium-sized Companies Respecting Accounting Legislation Changes, Procedia Economics and Finance, 39: 433-440.

Matemilola, B.T., Bany-Ariffin, A.N., Azman-Saini, W.N.W. et al. (2019). Impact of Institutional Quality on the Capital Structure of Firms in Developing Countries, Emerging Markets Review, 39: 175-209.

https://doi.org/10.1016/j.ememar.2019.04.003.

Mellichamp, A., Duncan. (2019). Profitability, Risk, and Investment in Conceptual Plan Design: Optimizing key financial parameters rigorously using NPV, Computers and Chemical Engineering, 128: 450-467.

MCNamara, A., Murro, P., Donohoe., \& Sheila, O. (2016). Countries lending infrastructure and capital structure determination: The case of European SMEs, Journal of Corporate Finance.

Moussawi, R., \& Kieschnick. (2018). Firm age, Corporate governance, and Capital structure choices, Journal of Corporate Finance, 48: 597-614.

Oji, U., J., \& Onyema, I., J. (2018). Financial Leverage and Profitability of Quoted food and beverage companies in Nigeria, International Journal of Research in Economics and Social Sciences (IJRESS). 8 (9): 1-15.

Premawati, I.G.A.S., and Darma, G.S. (2017). Pengaruh Ukuran Perusahaan, Pertumbuhan Penjualan, Struktur Aktiva, dan Profitabilitas Terhadap Struktur Modal (Penelitian Di Bursa Efek Indonesia Periode 2011-2015), Jurnal Ilmiah Akuntansi \& Bisnis, 2 (2): 272-286.

Riadevi, N.L.P.D., and Darma, G.S. (2016). Analisis Hubungan Indeks Harga Saham Gabungan dan Exchange Rate Terhadap Return Saham Dengan Profitabilitas Sebagai Variabel Intervening, Jurnal Manajemen \& Bisnis, 13 (1): 123-133.

Reig, A., \& Grau, J., A. (2018). Trade Credit and Determinants of Profitability in Europe. The case of the agri-food industry, International Business Review.

Ruzikna., \& Wulandari, I., D (2018). Pengaruh Pertumbuhan Penjualan dan Ukuran Perusahaan.

Sadia, N.P.M.D., \& Maradona, A.F. (2019). Ukuran Perusahaan, Kepemilikan Institusional, Struktur Kapital dan Nilai Perusahaan Publik di Indonesia, Jurnal Manajemen dan Bisnis, 16 (1): 87-102. 
Sampurno, D.R., \& Guna, A.M. (2018). Faktor-faktor yang mempengaruhi Struktur Modal pada perusahaan makanan dan minuman yang terdaftar di BEI periode 2012-2016. Diponegoro Journal of Management, 7 (2): 1-12.

Sridharan, P., \& Thiyagarajan, S. (2017). Firm Characteristics, Corporate Governance And Capital Structure Adjustments: A Comparative Study of Listed Firms in Sri Lanka And India, IIMB Management Review. https://doi.org/doi:10.1016/j.iimb.2017.10.002.

Shah, A., Shah, A., H., Smith, M., J., \& Labianca, G. (2016). Judicial Efficiency and Capital Structure: An International Study, Corfin.

Shihadeh, S.E., \& Barranco, E.R. (2015). Business structure, ethnic shifts in labor markets, and violence: The link between company size, local labor markets, and non-Latino homicide, Social Science Research, 49: 156-166.

Sturm, B., Jones-Chester, M., Schmitt, B., \& Meyers, S. (2016). Energy Efficiency, Carbon Emissions, and Measures Towards their Improvement in the food and beverage sector for six European Countries, Energy, 104: 266-283.

Tempo. Co. (2018). Industri Makanan dan Minuman Menjadi Sektor Andalan di 2018. https://bisnis.tempo.co/read/1058746/industri-makanan-dan-minuman-menjadisektor-andalan-di-2018.

Walker, T., Pukthuanthong, K., \& Bitar, M. (2017). The effect of capital ratios on the risk, efficiency and profitability of banks: Evidence from OECD countries, Journal of International Financial Markets, Institutions \& Money.

Yang, Z., \& Tan, Y (2016). Contingent Capital, Capital Structure, and Investment, North American Journal of Economics and Finance, 35: 56-73.

Yuliawati, L. (2017). Analisis Struktur, Prilaku, dan Kinerja Industri Makanan dan Minuman di Indonesia, Jurnal Ecodemica. 